\title{
EHMTI-0390. The attitude of migraineurs to alternative therapies
}

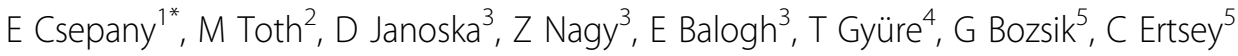 \\ From 4th European Headache and Migraine Trust International Congress: EHMTIC 2014 \\ Copenhagen, Denmark. 18-21 September 2014
}

\section{Introduction}

The growing interest in alternative therapies (ALTs) is a worldwide phenomenon. Headache and migraine are among the top five conditions treated with such therapies, although scientific proof of efficacy is often lacking.

\section{Objective}

To explore the attitude of Hungarian migraineurs to alternative therapies.

\section{Methods}

Questionnaire survey conducted at two headache centres. A willingness to pay approach was used to assess the importance of alternative therapies for the patients.

\section{Results}

75 patients (mean age: $35.4 \pm 12.4$ years; 70 women) were enrolled. Thirty-four (44\%) had already tried at least one ALT. Ninety percent of the patients were willing to pay for ALTs recommended for their migraines, on average $19 \%$ of the Hungarian monthly net minimum wage. If scientific evidence of efficacy was lacking, 57\% of the patients would pay for the ALTs (on average 14\% of the net minimum wage). If the ALTs were associated with side effects, only $33 \%$ of patients would try them. Actual use and willingness to use was higher among patients with higher levels of education. If two therapies were equally effective, $65 \%$ would choose an ALT and $11 \%$ would prefer the conventional therapy ( $24 \%$ having no preference). If the treatments' side effects were equal, $36 \%$ would choose the ALT and $22 \%$ the conventional treatment $(\mathrm{p}<0.001$ for the differences between the two scenarios).

'János Szentágothai Neurosciences PhD School, Semmelweis University, Budapest, Hungary

Full list of author information is available at the end of the article

\section{Discussion}

The majority of migraineurs had positive attitudes towards ALTs. This is probably due to ALTs being considered safer than conventional therapies. Patients with higher levels of education have a higher preference for ALTs.

No conflict of interest.

\section{Authors' details}

'János Szentágothai Neurosciences PhD School, Semmelweis University, Budapest, Hungary. ${ }^{2}$ Headache Service, Vaszary Kolos Hospital, Esztergom, Hungary. ${ }^{3}$ Faculty of Medicine, Semmelweis University, Budapest, Hungary.

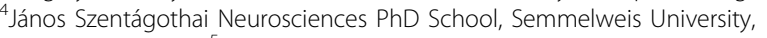
Budapest, Hungary. ${ }^{5}$ Department of Neurology, Semmelweis University, Budapest, Hungary.

\section{Published: 18 September 2014}

doi:10.1186/1129-2377-15-S1-M4

Cite this article as: Csepany et al.: EHMTI-0390. The attitude of migraineurs to alternative therapies. The Journal of Headache and Pain 2014 15(Suppl 1):M4.

\section{SpringerOpen ${ }^{\circ}$}

(C) 2014 Csepany et al; licensee Springer. This is an Open Access article distributed under the terms of the Creative Commons Attribution License (http://creativecommons.org/licenses/by/2.0), which permits unrestricted use, distribution, and reproduction in any medium, provided the original work is properly cited.
Submit your manuscript to a SpringerOpen ${ }^{\circ}$ journal and benefit from:

- Convenient online submission

- Rigorous peer review

- Immediate publication on acceptance

- Open access: articles freely available online

- High visibility within the field

- Retaining the copyright to your article

Submit your next manuscript at $>$ springeropen.com 